Journal of Health Promotion and Behavior (2016), 1(1): 32-40

https://doi.org/10.26911/thejhpb.2016.01.01.05

\title{
The Effect of Peer Support Group on Depression and Quality of Life among People Living with HIV/AIDS in Kediri East Java
}

\author{
Astika Rasyiid ${ }^{1,2)}$, Ruben Dharmawan²), Supriyadi Hari Respati²) \\ 1) Diploma III Midwifery of Tulungagung University, East Java \\ 2) Public Health Science Study Program, Postgraduate Program of Sebelas Maret University
}

\begin{abstract}
Background: People living with Human Immunodeficiency Virus/Acquired Immune Deficiency Syndrome or HIV/AIDs encounter such problems as society stigma and depression that can affect their quality of life in the term of physical, mental, and social health. Social support should be improved from individual, family, Peer Support Group (PSG), and government. PSG serves to help PLWHA feel not lonely, to give opportunity of seeing others, of sharing information about newest treatment and local support service, to reduce isolation, to improve social support, and to reduce stigma in order to achieve better quality of life and to reduce depression. The objective of the research was to analyze the effect of KDS on depression and quality of life among PLWHA in Friendship Plus Peer Support Group in Kediri City.

Subjects and Method: This was an analytic observational study with cross-sectional design. This was conducted at Friendship Plus Peer Support Group in Kediri, East Java in May to July 2016. The sample consisted of 60 subjects taken using simple random sampling. The dependent variable was quality of life. The independent variables were peer support group, family income, education, time of HIV infection, age, work, and married. Data was collected by a set of questionnaire and analyzed by multiple linear regression.

Results: The result of research showed that there was a statistically significant effect of Peer Support Group ( $\mathrm{b}=-0.60 ; 95 \% \mathrm{CI}=-0.82$ to $0.38 ; \mathrm{p}<0.001)$ on the reduced depression in PLWHA. Depression was affected by family income of $88.8 \%(b=-8.68 ; 95 \% \mathrm{CI}=0.01 ; \mathrm{p}=0.021)$ and education $(b=-7.86 ; 95 \% \mathrm{CI}=-14.05$ to $1.67 ; \mathrm{p}=0.014)$. There was a statistically significant effect of Peer Support Group on the improved quality of life among PLWHA $(b=0.32 ; 95 \% \mathrm{CI}=0.09$ to 0.53 ; $\mathrm{p}=0.005)$. Quality of life was affected by family income of $92.3 \%(\mathrm{~b}=1.36 ; 95 \% \mathrm{CI}=0.01 ; \mathrm{p}<0.001)$ and education $(\mathrm{b}=20.84 ; 95 \% \mathrm{CI}=14.75$ to $26.93 ; \mathrm{p}<0.001)$.

Conclusion: This research concluded that there was an effect of peer support group on the reduced depression among PLWHA and there was an effect of peer support group the improved quality of life among PLWHA.
\end{abstract}

Keywords: peer support group, depression, quality of life, PLWHA

Correspondence:

Astika Rasyiid· Diploma III Midwifery of Tulungagung University, East Java.

\section{BACKGROUND}

Human Immunodeficiency Virus or HIV causes a contagious and very deadly disease known as Acquired Immune Deficiency Syndrome or AIDS. World Health Organization (WHO) states HIV/ AIDS and Tuberculosis (TB) as the most deadly epidemic and has been a contagious disease that becomes the health problem of global com- munity throughout the world, including Indonesia. This problem entails the number of HIV/AIDS and TB incidence that has been increasing over the years along with high mortality rate.

In addition to the increased mortality rate, HIV/AIDS epidemic has been overwhelming all society layers in all countries (Kusuma, 2011). When individuals are stat- 
ed as having been infected by HIV, most of them display psycho-social changes namely: living within stress, having depression, sensing the lack of social support and having behavioral changes (Nasronudin, 2007).

Data cases of HIV/AIDS in Indonesia reported through September 2014 from Directorate General CDD and EH Ministry of Health, Republic of Indonesia, shows that since it has been found in Indonesia for the first time from 1987 until September 2014, HIV/AIDS cases have been spread in 381 (76\%) out of 498 regencies/ cities in throughout all provinces of Indonesia. Until 2005, the number of HIV epidemic that has been reported is 859 cases in which 112 cases were ended up in death; in 2014, the number HIV epidemic that has been reported is 22,869 .

The cumulative number of HIV infection that has been reported until September 2014 is 150,296 cases and the Province of East Java occupied the second place after the Province of Jakarta Special Capitol Region $(19,249)$. On the other hand, the cumulative number of AIDS disease that has been reported from 1987 until September 2014 is 55,799 cases. Then, the highest number of AIDS case is found in the Province of Papua $(10,184)$, followed by East Java $(8,976)$ and Jakarta Special Capital Region $(7,477)$. The mortality rate (CFR) itself has decreased from $3.79 \%$ in 2012 to $0.46 \%$ in September 2014 (Ditjen PP dan PL Kemenkes RI, 2014). According to the Office of Health in the Regency of Kediri, in 2014 there were 615 HIV/AIDS patients and 183 of them were dead.

According to Kusuma (2011), HIV/ AIDS patients' quality of life has been influenced by demographic characteristics. Based on a quality of life surveillance regarding health in the United States of America from 1993-2002, there have been several factors that determine the quality of life namely sex, age, ethnicity or race, marriage status, education, income, employment status, health insurance and health factors. Then, there are also other factors that might influence HIV/ AIDS patients' quality of life namely infection, antiretroviral therapy, social support, number of $\mathrm{CD}_{4}$, medication compliance, occupation, gender, symptoms, depression and family support (Disa et al., 2014).

According to WHO, PLWHA quality of life is influenced by physical aspects, ARV dependency level, environment, peer support and spiritual aspects. Social support might help PLWHA in dealing with their problems both physically and psychologically. Therefore, improving social support should be pursued by the individuals, the family, PLWHA observing institutions, the peer support group (PSG) and the government (Rozi, 2016).

PSG is a group in which two people or more who have been directly infected or influenced by HIV gather around and support one to another. PSG members are PLWHA and people who live with HIV/ AIDS (PLW$\mathrm{HA}$ ) or the combination of both groups. At the beginning, a group might be the consolidation of PLWHA with different background and of people who have desires to establish a more specific group, for example: a group that only consists of PLWHA, a group with specific background (Transvestites, IDU, Female Group and others) or a combination of PLWHA and people who live with PLWHA. The pattern of PSG support starts with a closed meeting for PLWHA in which they may share their experience. This pattern then will expand from shared learning activities until wider involvement in disseminating and advocating HIV-related matters. This pattern is also helpful in the implementation of National Act Planning Strategies (SRAN, Strategi 
Journal of Health Promotion and Behavior (2016), 1(1): 32-40

https://doi.org/10.26911/thejhpb.2016.01.01.05

Rencana Aksi Nasional) 2010-2014 which is aiming at improving HIV/AIDS patients' quality of life.

The roles of peer support are namely: helping PLWHA and people who live with PLWHA so that they do not feel alone in dealing with their problems, providing opportunities to meet other people and build friendship, helping them to be stronger and more confident, serving as a medium for performing activities, gathering people from various and different background, improving mutual trust and tolerance, providing resources from one to another and providing information i.e. regarding latest medication or local support service, improving community awareness regarding the situations that the groups members should be dealing with by showing more humane expressions toward PLWHA and representing stronger voice for pursuing changes (advocate) (Mardhiati \& Handayani, 2011).

Peer support also has another role in decreasing the socio-economic impacts of HIV/ AIDS toward PLWHA and their family. Impact mitigation programs are provided to these unlucky people who need support. The provision of educational opportunity, health service, nutrition and access to economic aids are the main components of these programs for people who have been infected and been impacted by HIV, orphans, single parents and widows in order to attain support access toward income improvement, skill training programs and quality of life improvement programs. This provision is pursued through the cooperation among the Ministry of Social Affairs, the Ministry of National Education and the peer support. The criteria in determining the mitigation needs should be developed in order to identify the appropriate programs for those who need them (scope, fund, duration and target) (Mardhiati \& Handayani, 2011). 
understand "The Effect of Peer Support Group on Depression and Quality of Life among People Living with HIV/AIDS in Kediri East Java 2016.”

\section{SUBJECTS AND METHOD}

The type of study that the researchers selected was analytical observational research by means of cross-sectional approach. The study was conducted in PSG Friendship Plus City of Kediri for two months from May until July 2016. The subjects in the study were 60 persons.

The sampling technique used was simple random sampling. The inclusion criteria were: (1) people living with HIV/ AIDS both the group that had a risk of being infected by HIV/AIDS such as Female Prostitute, Gay, High-Risk Male, Transvestites and their family/ couple; (2) willing to be the respondents in this study and the willingness was shown by signing the informed consent; (3) registered as the members of PSG Friendship Plus City of Kediri; and (4) attending routine activities that would be held by the committee of PSG Friendship Plus City of Kediri in June 2016. Then, the exclusion criteria were: people living with HIV/ AIDS who had not been registered as the members of PSG Friendship Plus City of Kediri. For the data processing, the researchers made use of Pearson product moment correlation test and multivariate analysis by means of multiple linear regressions.

\begin{tabular}{l} 
RESULTS \\
\hline 1. Univariate analysis \\
The characteristics of research subjects in \\
PSG Friendship Plus City of Kediri that had \\
been attained from 6o respondents were as \\
follows: 31 respondents (51.70\%) were 20- \\
35 years old 33 respondents were female. \\
Then, 47 respondents (78.30\%) had \\
"Single," "Widow" or "Widower" status, 41
\end{tabular}

respondents (68.30\%) had high education degree (senior high school and university degree), 17 respondents (28.30\%) were employees, 36 respondents (60.00\%) earned income that had been under the minimum regional wage, 48 respondents (80.00\%) had been diagnosed being infected by HIV/AIDS for more than 12 months and 50 (83.30\%) respondents had high-risk factors criteria (Female Prostitute, Gay, High-Risk Male, Transvestites).

The researchers also gathered description regarding the PSG, the depression and the quality of life from the 60 respondents. Based on this description, 37 respondents $(61.70 \%)$ found that this PSG had been strong, 45 respondents (75.00\%) had been in heavy depression and 38 respondents $(63.30 \%)$ had high quality of life.

\section{Bivariate Analysis}

Table 1. Bivariate analysis of Pearson correlation for the influence of PSG toward Depression

\begin{tabular}{lcc}
\hline \multicolumn{1}{c}{ Independent variables } & $\mathbf{r}$ & $\mathbf{p}$ \\
\hline Strong PSG & -0.85 & $<0.001$ \\
Family income (Rp/month) & -0.60 & $<0.001$ \\
$\begin{array}{l}\text { Education } \geq \text { Senior High } \\
\text { School Degree }\end{array}$ & -0.68 & $<0.001$ \\
Time of HIV infection stated & -0.06 & 0.657 \\
$\begin{array}{l}\text { by the doctor (month) } \\
\text { Age (years old) }\end{array}$ & 0.19 & 0.148 \\
Working & -0.16 & 0.226 \\
Married & 0.21 & 0.106 \\
Female & 0.10 & 0.458 \\
\hline
\end{tabular}

Table 2. Bivariate analysis of Pearson correlation for the Influence of PSG toward Quality of Life

\begin{tabular}{lcc}
\hline \multicolumn{1}{c}{ Independent variables } & $\mathbf{r}$ & $\mathbf{p}$ \\
\hline Strong PSG & 0.81 & $<0.001$ \\
$\begin{array}{l}\text { Familyincome(Rp/ month) } \\
\text { Education } \geq \text { Senior High }\end{array}$ & 0.62 & $<0.001$ \\
$\begin{array}{l}\text { School degree } \\
\text { Time of HIV infection }\end{array}$ & 0.83 & $<0.001$ \\
stated by the doctor & & \\
(month) & 0.25 & 0.056 \\
Year (age) & & \\
Working & -0.20 & 0.123 \\
Married & 0.21 & 0.110 \\
Female & -0.18 & 0.172 \\
& -0.07 & 0.600 \\
\hline
\end{tabular}


Journal of Health Promotion and Behavior (2016), 1(1): 32-40

https://doi.org/10.26911/thejhpb.2016.01.01.05

\section{Analisis Multivariate}

Family income $\geq$ regional minimum wage has influenced the decrease of PLWHA depression and the influence is statistically significant. PLWHA whose family income $\geq$ minimum regional wage have decreased the depression approximately 8.68 unit lower than those whose family income $<$ minimum regional wage $(b=-8.68 ; 95 \% \mathrm{CI}=0.01$; $\mathrm{p}=0.021)$.

Table 1 shows the influence of PSG toward PLWHA depression and the influence is statistically significant. PLWHA with strong PSG have decreased their depression approximately 0.60 unit lower in comparison to those with weak PSG $(b=-0.60$; 95\% CI= -0.82 to $-0,38 ; \mathrm{p}<0.001$ ).

Table 3. Results of linear regression analysis for the Influence of PSG toward PLWHA's Quality of Life in PSG Friendship Plus City of Kediri

\begin{tabular}{|c|c|c|c|c|}
\hline \multirow{2}{*}{ Independent variables } & \multirow[t]{2}{*}{$\mathbf{b}$} & \multicolumn{2}{|c|}{ CI 95\% } & \multirow{2}{*}{$\mathbf{p}$} \\
\hline & & Lower & Upper & \\
\hline Constant & 9.33 & -7.63 & 26.30 & 0.275 \\
\hline Strong KDS & 0.32 & 0.09 & 0.53 & 0.005 \\
\hline Family income (Rp/month) & 1.36 & 0.01 & 0.01 & $<0.001$ \\
\hline Education $\geq$ Senior High School Degree & 20.84 & 14.75 & 26.93 & $<0.001$ \\
\hline Time of HIV infection stated by the doctor (month) & -0.01 & -0.08 & 0.08 & 0.980 \\
\hline Year (age) & -0.02 & -0.30 & 0.26 & 0.873 \\
\hline Working & 0.57 & -0.56 & 1.63 & 0.278 \\
\hline Married & 0.23 & -4.12 & 4.56 & 0.916 \\
\hline Female & -0.49 & $-3 \cdot 38$ & 2.39 & 0.732 \\
\hline \multicolumn{5}{|l|}{$\mathrm{N}$ observation $=60$} \\
\hline \multicolumn{5}{|l|}{ Adjusted $\mathrm{R}^{2}=92.3 \%$} \\
\hline $\mathrm{p}<0.001$ & & & & \\
\hline
\end{tabular}

Age has influenced the increase of PLWHA depression but the influence is statistically insignificant. Every one-year escalation on the age has increased the depresssion approximately 0.03 unit $(b=0.03 ; 95 \% \mathrm{CI}=-$ 0.25 to $0.32 ; \mathrm{p}=0.822$ ).

Working has influenced the decrease of PLWHA depression but the influence is statistically insignificant. PLWHA who are working have decreased the depression approximately 0.02 unit lower than those who are not working $(b=0.02 ; 95 \% \mathrm{CI}=-1.08$ to 1.04; $\mathrm{p}=0.971)$.
Education $\geq$ senior high school degree has influenced the decrease of PLWHA depression and the influence is statistically significant. PLWHA whose education $\geq$ senior high school degree has decreased the depression approximately 7.86 units lower than those whose education $<$ senior high school degree $(b=-7.86 ; 95 \% \mathrm{CI}=-14.05$ to 1.67; $\mathrm{p}=0.014$ ).

Time of HIV infection stated by the doctor has influenced the increase of PLWHA depression but the influence is statistically insignificant. Every one month-escalation on the time of HIV infection has increased the depression approximately 0.09 unit $(b=0.08 ; 95 \% \mathrm{CI}=-0.01$ to -0.16 ; $\mathrm{p}=0.053)$. 
Adjusted R2 $=88.80 \%$ implies that the independent variables in the linear regression model altogether had been able to predict or to explain the depression variable and been able to decrease the depression approximately $88.80 \%$, while the remaining $11.20 \%$ is influenced by other variables that are not in the linear regression model. From $\mathrm{p}<0.001$, the researchers might conclude that the estimated linear regression model has been feasible for explaining the influence of independent variables toward the dependent variables.

Table 3 shows the influence of PSG toward the improvement of PLWHA quality of life and the influence is statistically significant. PLWHA with strong PSG have improved quality of life approximately 0.32 unit higher than PLWHA with weak PSG $(b=0.32 ; 95 \% \mathrm{CI}=0.09$ to $0.53 ; \mathrm{p}=0.005)$.

Family income $\geq$ minimum regional wage has influenced the improvement of PLWHA quality of life and the influence is statistically significant. PLWHA whose family income $\geq$ minimum regional wage has improved the quality of life approximately 0.32 higher than those whose family income $<$ minimum regional wage $(b=1.36$; 95\% CI= 0.01; $\mathrm{p}<0.001)$.

Education $\geq$ senior high school degree has influenced the improvement of PLWHA quality of life and the influence is statistically significant. PLWHA whose education $\geq$ senior high school degree have improved the quality of life approximately 20.84 unit higher than those whose education $<$ senior high school degree $(b=20.84 ; 95 \% \mathrm{CI}=$ 14.75 to 26.93; $\mathrm{p}<0.001$ ).

Time of HIV infection stated by the doctor has influenced the improvement of PLWHA quality of life but the influence is statistically insignificant. Every one-month escalation on the time of HIV infection have improved the quality of life approximately
0.01 unit $(b=0.01 ; 95 \% \mathrm{CI}=-0.08$ to 0.08 ; $\mathrm{p}=0.980$ ).

Age has influenced the reduction of PLWHA quality of life but the influence is statistically insignificant. Every one-year escalation on the age has reduced the quality of life approximately 0.02 unit $(\mathrm{b}=$ $0.02 ; 95 \% \mathrm{CI}=-0.30$ to $0.26 ; \mathrm{p}=0.873$ ).

Working has influenced the improvement of PLWHA quality of life but the influence is statistically insignificant. PLWHA who are working have improved the quality of life approximately 0.57 unit lower than those who are not/do not working $(b=0.57$; 95\% $\mathrm{CI}=0.56$ to $1.63 ; \mathrm{p}=0.278$ ).

Married has influenced the improvement of PLWHA quality of life but the influence is statistically insignificant. PLWHA who are married have improved the quality of life approximately 0.23 unit higher than those who are not/do not married $(b=0.23$; 95\% $\mathrm{CI}=-4.12$ to $4.56 ; \mathrm{p}=0.916$ ).

Female has influenced the improvement of PLWHA quality of life but the influence is statistically insignificant. Female PLWHA have reduced the quality of life approximately 0.49 unitlower than male PLW$\mathrm{HA}(\mathrm{b}=-0.49 ; 95 \% \mathrm{CI}=-3.38$ to 2.39 ; $\mathrm{p}=$ 0.732 ).

Adjusted R2 $=92.30 \%$ implies that the independent variables in the linear regression model altogether have been able to explain or to predict the variation on quality of life and been able to improve the quality of life approximately $92.30 \%$. From $\mathrm{p}<0.001$ for the overall model, the researchers have found an implication that all independent variables in their relation to the quality of life have been statistically significant.

\section{DISCUSSION}

\section{The Influence of PSG toward PLWHA Depression}


Journal of Health Promotion and Behavior (2016), 1(1): 32-40

https://doi.org/10.26911/thejhpb.2016.01.01.05

PSG refers to a group that consists of two people or more who have been infected or been impacted by HIV and in PSG these people gather themselves and support one to another. The members of PSG are PLWHA, people who lived with PLWHA or the combination of both groups. At the beginning PSG was a consolidation of PLWHA who came from different background and in this consolidation they sensed the needs to form a more specific group such as PLWHA-specific group or PLWHA with certain background (Transvestites, IDU, Female and more) or the combination of PLWHA and people who live with PLWHA. Support Group or SG plays a role in coordinating, accommodating, aspiring and meeting the needs of PSG that they serve; in the same time, SG also develops critical awareness, guard PSG and guide PSG by upholding equality and by serving as an advocate through PLWHA involvement within the advocating process. SG serves to prevent/ to anticipate the occurrence of inter PSG conflicts, to provide support for PSG, to provide opportunities for PSG in developing well together, to ensure that the fund that SG has provided will be spent appropriately and to serve as information medium and channel for all PSGs under service (Mardhiati \& Handayani, 2011).

A study by Yuniar (2013) found that PSG has been an external factor that influences ARV therapy compliance. On the other hand, Alfiyyatur (2012 in Yuswanto et al., 2014) concluded that PSG serves to motivate and to accompany PLWHA. The buddy task for PSG as PLWHA companion has been to provide in-depth information regarding HIV/AIDS (Mardhiati \& Handayani, 2011).

Peer support is heavily demanded in order that PLWHA will be able to decrease their depression. In this case, the role of PSG is to achieve a better quality of life for
PLWHA and people who live with PLWHA. Technically, the peer support is provided by assisting PLWHA and people who live PLWHA so that they will not feel alone in dealing with their problems, by providing opportunities to meet other people and build friendship, by helping them to be more confident and stronger, by serving as a medium for multiple activities, by introducing people from different background, by expanding mutual understanding and tolerance and by mutually sharing resources, ideas, and information for example regarding latest medication or local support service and alike.

On the contrary, if this group is able to perform their functions well then PLWHA will still sense that there are people who care about them, there are hopes to share their thoughts and feelings, there are hopes to be provided with attention and assistance. Human beings have physiological and psychological side. That psychological need is predominant for HIV/ AIDS patients. If PSG does not function well then the patients will sense that they do not have any hopes and, as a result, their psychological burden will increase and this will trigger the occurrence of depression.

The results of a study by Pardita and Sudibia (2014) was contradictory to the concept regarding the economic impact toward HIV/AIDS patients, which stated that HIV/AIDS epidemic will cause high cost both for the patients and the hospitals. The reason was that the cure for this disease has not been discovered and therefore both the patients and the hospitals should spend their budget only for tending and prolonging the patients' life. People who have been infected with HIV/AIDS will have financial changes due to their disease. The fund that they need for medication and treatment will increase over the time, while their income is still the same and in fact, it 
might be reduced. Eventually, the biggest possibility is that these people will have difficulties in attaining the medication and treatment fund. Such changes occur because the patients lose their living, their savings, family assistance sources and more; therefore, continuous studies should be conducted and other fund sources will be necessary for performing preventive actions. Due to experiencing changes significantly, HIV/AIDS respondents in the study by Pardita and Sudibia (2014) stated that the medicines that they had consumed made them able to return to their normal physical condition so that they might go to work again routinely in order to meet their economic needs. Furthermore, the medicines that had been administered to HIV/ AIDS patients by the government and foreign aids were free so that the patients did not need to spend their cash. This has been one of the responsibilities and attention that the government and foreign donors give toward HIV/AIDS patients.

American Psychological Association (2005) in Trilistya (2006) stated that educational level correlates to depression, namely that depression occurs more frequently on people with low educational level, whereas in the study depression has occured on PLWHA with high educational level namely $>$ senior high school degree. Being infected by HIV/AIDS has been a heavy stressor for PLWHA in addition to the fact that this disease causes death; as a result, the number of PLWHA stressor in this study becomes greater. With such heavy stressor, each people, regardless educational level, might suffer from depression. The depression that occurs might go away or might need treatment depending on each individual.

\section{The Influence of Peer Support Group toward PLWHA Quality of Life}

The results of a study by Yuswanto et al. (2014) showed that PSG has displayed good role in improving PLWHA quality of life. PSG has been very helpful for PLWHA when they were undergoing medication and treatment both the inpatient one and the outpatient one. In the cause of outpatient treatment or home treatment, PSG role has been to monitor the food and medicine administration, to drive PLWHA when they should undergo treatment and to provide mental and spiritual support. In addition, PSG has also been motivating PLWHA to keep fighting off their disease and to do physical activities that they might perform according to their capability.

These results are in accordance with a study by Worthington and Krentz (2005) in which social-economic status (income) has been a significant factor that influences quality of life. In addition, these results are also in accordance to a study by Wig et al. (2006 in Kusuma, 2011) which found that income/earnings has been one of the factors that influences HIV/AIDS patients' quality of life. On another study by Nazir (2006 in Kusuma, 2011), it was uncovered that people with income that could not meet the daily needs had worse quality of life in comparison to those who have sufficient income. PLWHA who have sufficient family income is not only able to support the fulfillment of their daily needs but also to afford the necessary treatment cost in relation to this disease so that they might keep their health rate (Kusuma, 2011). This matter might certainly influence PLWHA quality of life.

The results of a study by Nirmal et al. (2008 in Kusuma, 2011) found that educational level has been a significant factor that influences the quality of life. Further- 
Journal of Health Promotion and Behavior (2016), 1(1): 32-40

https://doi.org/10.26911/thejhpb.2016.01.01.05

more, similar results were also found in a study by Greeff et al. (2009; Wig et al., 2006 in Kusuma, 2011) which stated that educational level has been one of the factors that influence HIV/AIDS patients' quality of life. In another study by Nazir (2006; Lucas et al., 2006; Afiyah, 2010 in Kusuma, 2011), it was found that individuals with low education level (under senior high school degree) has poor quality life in comparison to those with high educational level.

\section{REFERENCE \\ $\overline{\text { Alfiyyatur R (2012). Peran Buddy Sebagai }}$ Pendamping ODHA. http://www. kom pas. com. Jakarta 2012. diakses 13- 02-2016.}

American Psychological Association (200 5). What is Depression? http://www. apa.org/ppo/issues.htm.

Depkes RI (2006). Situasi HIV/AIDS di Indonesia Tahun 1987-2006. Jakarta: Pusat Data dan Informasi Depkes RI.

Disa NS, Parjo, Ariyani PD (2014). FaktorFaktor yangMempengaruhi Kualitas Hidup Penderita HIV yang Menjalani Rawat jalan di Care Support and Treatment (CST) Rumah Sakit Jiwa Daerah Sungai Bangkong Kota Pontianak. Universitas Tanjungpuran Pontianak.

Kusuma H (2011). Hubungan Antara Depresi dan Dukungan Keluarga dengan Kualitas Hidup Pasien HIV/ AIDS yang Menjalani Perawatan di RSUPN Cipto Mangunkusumo Jakarta. Depok: Program Pascasarjana Fakultas Ilmu Keperawatan Kekhususan Keperawatan Medikal Bedah Universitas Indonesia.
Mardhiati R, Handayani S (2011). Peran Dukungan Sebaya Terhadap Peningkatan Mutu Hidup ODHA Di Indonesia. Yayasan Spiritia bekerja sama dengan Lembaga Penelitian dan Pengembangan Universitas Muhammadiyah Prof. DR. Hamka. Komisi Penanggulangan AIDS Nasional, Ford Foundation, AusAID. http:// spiritia. or.id/diakses 14 Februari 2016.

Nasronudin (2007). Penyakit Infeksi Di Indonesia Solusi Kini Dan Mendatang. Airlangga University Press, Surabaya.

Pardita DPY, Sudibia IK (2014). Analisis Dampak Sosial, Ekonomi, dan Psikologis Penderita Hiv Aids di Kota Denpasar Analisis Dampak Sosial, Ekonomi, dan Psikologis Penderita HIV AIDS Di Kota Denpasar. Jurnal Buletin Studi Ekonomi 19 (2): 193-199.

Rozi RF (2014). Hubungan Dukungan Sosial dengan Kualitas Hidup ODHA pada Kelompok Dukungan Sebaya Solo Plus di Surakarta. Fakultas Ilmu Kesehatan Universitas Muhammadiyah Surakarta.

Salzer M (2002). Consumer-delivered services as a best practice in mental health care and the development of practice guidelines. Psychiatric Rehabilitation Skills 6: 355-382.

Trilistya S (2006). Tingkat Depresi Korban Tanah Longsor di Banjarnegara. Semarang: Fakultas Kedokteran Universitas Diponegoro Semarang.

Yuniar Y (2013). Terapi Eksternal dan Kepatuhan Mengonsumsi ARV pada Penderita HIV/AIDS. Buletin Penelitian Kesehatan 4(2): 72-83. 